\begin{tabular}{l}
\hline Missio Eclesiae \\
ISSN 2086-5368 (Print) \\
ISSN 2086-5368 (Online) \\
https://jurnal.i3batu.ac.id/index.php/me \\
Vol.9, No.2, pp. 98-118, 2020
\end{tabular}

\title{
Model Kepemimpinan Yesus Kristus Sebagai Pembawa Damai Bagi Resolusi Konflik di Kota Surakarta
}

\author{
Irawan Budi Lukmono, ${ }^{a}$ Gunaryo Sudarmanto ${ }^{b}$ \\ ${ }^{a}$ STT Gamaliel Surakarta: ibelodia@yahoo.com \\ ${ }^{b}$ Institut Injil Indonesia: revgsudarmanto@gmail.com
}

\section{INFO ARTIKEL ABSTRAK}

Sejarah Artikel:

Diterima:

06 Oktober 2020

Direvisi:

07 Oktober 2020

Disetujui:

30 Oktober 2020

Dipublikasi:

30 Oktober 2020

\section{Kata Kunci:}

\section{Kepemimpinan} pembawa damai, Yesus

Kristus, dan resolusi

konflik.

Keywords:

Leadership style of peacemaker, Jesus Christ, conflict resolution.

\begin{abstract}
Obyek dari penelitian ini adalah kepemimpinan pembawa damai bagi resolusi konflik. Penelitian ini menggunakan paradigm naturalistik dengan pendekatan kualitatif dan metode fenomenologi.

Tujuan penelitian ini untuk menjelaskan dan menemukan: (1) kepemimpinan pembawa damai, (2) kepemimpinan Yesus Kristus sebagi pembawa damai, (3) model kepemimpinan Yesus Kristus sebagai pembawa damai bagi resolusi konflik di kota Surakarta.

Pengumpulan data melalui pengamatan, wawancara, dan penelaahan dokumen tertulis. Analisis data dengan menggunakan analisis domain, analisis taksonomi, analisis komponensial, dan analisis tema.

Hasil dari penelitian adalah model kepemimpian pembawa damai bagi resolusi konflik di kota Surakarta yang memiliki tiga komponen: (1) kepemimpinan pembawa damai yang mencakup prinsip, upaya, dan karakter, (2) resolusi konflik, (3) dampak. Hasil penelitian ini dapat diterapkan para pemimpin Kristen dalam membangun perdamaian dan resolusi konflik di kota Surakarta.
\end{abstract}

\section{ABSTRACT}

The object of this research is peacemaking leadership for conflict resolution. This research using naturalistic paradigm with qualitative approach and phenomenology method.

Research have been conducted on strategies to find (1) leadership style of a peacemaker, (2) leadership of Jesus Christ as a peacemaker, (3) leadership of Jesus Christ as a peacemaker for conflict resolution in Surakarta.

Data was collected by direct observation, interview, and written document review. Data was analyzed with domain analysis, taxonomy analysis, componential and theme analysis.

The result of the research concluded that leadership model of peacemaking leadership for conflict resolution in Surakarta contained of three components: (1) A Peacemaker's leadership that consist of fundamentals, efforts, and character, (2) conflict resolution, (3) impacts. This result can be used by Christian leaders to build peace and conflict resolution. 


\section{PENDAHULUAN}

Surakarta adalah salah satu kota yang majemuk dan multikultural di propinsi Jawa Tengah. Dalam hal agama, Surakarta merupakan kota plural, dimana konstelasi keagamaan menunjukkan keberagaman agama di kota Surakarta, yaitu Islam, Kristen, Katholik, Hindu, Budha, Konghucu, dan aliran kepercayaan. Secara politis, Surakarta merupakan kota yang dikaitkan dengan kebangkitan nasional, sosialisme, dan gerakan keagamaan. Mengingat kota Surakarta adalah kota majemuk, tentu pernah terjadi konflik antaretnik maupun antaragama. Beberapa konflik yang pernah terjadi di kota Surakarta merupakan dinamika sosial akibat dari fragmentasi sosial dan etnisistas, kesenjangan ekonomi, kekuasaan politik, perbedaan budaya dan agama, serta tingkat pendidikan. Kota Surakarta menjadi tempat terjadinya konflik dan kekerasan sosial. Konflik ini terjadi atas dasar agama, etnisitas, afiliasi politik, dan kelas social rentetan konflik, kekerasan, maupun intoleransi dari tahun ke tahun terus terjadi. Surakarta menjadi tempat terjadinya konflik dan kekerasan sosial.Konflik ini terjadi atas dasar agama, etnisitas, afiliasi politik, dan kelas sosial. (Tadjoeddin:2002)

Kemajemukan budaya di kota Surakarta harus dikelola dengan serius. Harus ada usaha-usaha untuk mengurangi ketegangan, intoleransi, konflik, dan kekerasan. Realitas keagamaan yang mempresentasikan keanekaragaman seharusnya mempertautkan lapisanlapisan dan helaian dalam setiap agama dan di antara agama. Justru, kemajemukan yang saling terpaut ini memberikan identitas unik di mata dunia. (Maryam Kurniawati: 2014) Karena itu, pemimpin umat beragama (khususnya pemimpin Kristen) harus mengajarkan anggotanya untuk menghayati imannya dengan lebih utuh, mendalam, dan akurat, serta mempersiapkan untuk hidup bersama dalam masyarakat yang majemuk dengan penuh integritas. Hampir tiap tahun terjadi konflik, kekerasan atau intoleransi di kota Surakarta, sehingga menjadi catatan penting untuk dipikirkan bersama, bagaimana mencari jalan keluar melalui resolusi konflik. Berkaitan dengan hal ini, maka dibutuhkan kepemimpinan pembawa damai agar tercipta perdamaian dan keadilan. Berdasarkan permasalahan di atas mendorong peneliti untuk meneliti model kepemimpinan Yesus Kristus sebagai pembawa damai (peacemaking leadership) di kota Surakarta. Penelitian ini dilakukan dengan harapan pemimpin Kristen di kota Surakarta memperoleh penjelasan dan pemahaman mengenai model kepemimpinan Yesus Kristus sebagai pembawa damai (peacemaking leadership) yang alkitabiah, kontekstual, dan dapat diaplikasikan pada masa kini.

\section{KAJIAN LITERATUR}

Kehidupan damai adalah dambaan setiap manusia, termasuk masyarakat yang hidup di negara majemuk. Damai berarti masyarakat yang tidak lagi hidup dalam ketegangan yang mengarah kepada konflik-konflik horizontal bernuansa SARA. Masingmasing masyarakat mampu menjaga dan memelihara harmoni di antara kemajemukan dan keberbedaan. Sejahtera menunjuk kepada keadaan yang cukup secara sosial, ekonomi dan tidak ada kesenjangan sosial.

Damai mencakup empat bagian, yaitu damai dengan Allah (hubungan manusia dengan Allah, dan kesesuaian kehidupan manusia dengan prinsip penciptaannya), damai dengan diri sendiri (pribadi), damai dalam kehidupan bermasyarakat, dan damai dengan lingkungan (pemeliharaan dan pemanfaatan sumberdaya alam dengan baik). Damai sejati adalah damai yang dinamis, pastisipatif, dan berjangka panjang. Damai dapat diwujudkan dalam nilai-nilai kemanusiaan universal di dalam kehidupan keluarga, sekolah, kampus, komunitas, masyarakat, bangsa dan negara. (State of the World Forum,1999) Perdamaian sejati bukanlah tiadanya perang dan kekerasan saja, tetapi juga hadirnya keadilan. 


\section{Kepemimpinan Yesus Kristus sebagai Pembawa Damai}

Kepemimpinan adalah keseluruhan kemampuan, tindakan, sikap dan perilaku pemimpin dalam menginspirasi, memengaruhi, menggerakkan, bahkan mengarahkan orang lain untuk mewujudkan visi-misi. Dalam pelaksanaan kepemimpinan tidak bisa lepas dari pemimpin, organisasi, manajemen, dan administrasi. Kepemimpinan yang sehat memiliki: karakter, perspektif, keberanian, dan kebaikan.

\section{Pengertian Kepemimpinan Pembawa Damai}

Kepemimpinan pembawa damai adalah kepemimpinan yang membawa perdamaian serta memiliki isi hati, karakteristik, kekuatan mengusahakan dan membawa damai. (www.yakobtomatala.com) Kepemimpinan pembawa damai memiliki karakter kuat untuk memperjuangkan kebenaran. Ketika kebenaran ada, maka akan muncul damai sejahtera. Kepemimpinan pembawa damai terus mengusahakan terjadinya damai, menabur kebenaran tentang perdamaian.

Dalam kepemimpinan pembawa damai, terdapat pemimpin yang hidup dalam kebenaran. Isi hatinya terpaut pada kebenaran Allah, hidupnya telah dibebaskan kebenaran (Yoh. 14:6), pikiran dan akal budinya dibaharui, sehingga ia dapat melaksanakan kebenaran (Yoh. 8:31-32; 14:27). Ia juga membagikan kebenaran kepada orang-orang yang dipimpin dan diajar, sehingga mereka mengalami kebenaran yang membawa damai sejahtera yang kekal. Pemimpin pembawa damai hidup dalam integritas yang matang. Ia dapat mempertanggungjawabkan hidupnya dengan melakukan kebenaran, menjauhi kejahatan.

Pemimpin pembawa damai terus mencitrakan kehidupan dan kualitas kepemimpinannya. Ia dapat menjaga hatinya, bijaksana, bersih kelakuannya, perkataannya membawa berkat, dampak, dan kehidupan. Pemimpin pembawa damai mengakibatkan orang-orang di sekitarnya mengalami ketenangan, sukacita, ketenteraman, kebahagiaan, dan damai sejahtera. Pemimpin pembawa damai dapat meneguhkan dan menguatkan kehidupan dan kepemimpinannya. Ia akan berdiri teguh dalam menjaga nilai-nilai kebenaran. Nilai-nilai kebenaran akan meningkatkan kapasitas, harkat, martabat, dan derajat kepemimpinannya. Pemimpin pembawa damai akan menciptakan damai di tengah kekacauan hidup. Pemimpin pembawa damai didorong oleh iman mereka dan memiliki kapasitas luar biasa untuk memahami orang lain secara mendalam dan mengalami, dengan penuh kasih sayang, harapan dan rasa sakit mereka. (Little, 2007) Ia memiliki kasih yang begitu kuat, sehingga bisa meluluhkan hati musuh. (Moon, 1977) Tidak peduli seberapa intens dua musuh telah saling membenci, kasih itu sangat kuat sehingga kasih dapat menyembuhkan keretakan itu.

\section{Prinsip-Prinsip Kepemimpinan Pembawa Damai}

Prinsip merupakan suatu pernyataan fundamental atau kebenaran umum maupun individual yang dijadikan sebagai sebuah pegangan, panduan atau pedoman untuk berpikir atau bertindak (bertingkah laku). Prinsip adalah asas atau dasar berpikir, dan berperilaku. Prinsip-prinsip yang menopang kepemimpinan pembawa damai yaitu: (Moon, 1977) Pertama, hidup dalam kebenaran. Kedua, konsisten. Konsisten dalam hal mempraktikan kebenaran dalam kehidupan sehari-hari. Ketiga, beritegritas. Berintegritas dalam membawa dan menciptakan perdamaian dalam lingkungan. Keempat, komitmen. Komitmen untuk memperjuangkan keadilan, pembebasan dan kemerdekaan, membawa damai sebagai peneguh kepemimpinannya di tengah dunia yang penuh dengan kebenciaan, konflik, dan permasalahan.

Kelima, iman dan nilai. Setiap pemimpin pembawa damai harus dan perlu memegang teguh prinsip-prinsip universal yang mengacu kepada prinsip iman yang 
mengedepankan nilai-nilai pribadi antar manusia dengan Allah, manusia dengan manusia, dan manusia dengan lingkungan. Prinsip-prinsip ini adalah: kasih, kebenaran, kejujuran, keadilan, kedamaian, integritas, kedisiplinan, dan kepercayaan. (Aritonang \& Gultom, 2009) Keenam, kebijaksanaan. Perdamaian dunia dapat sepenuhnya dicapai hanya ketika kebijaksanaan dan upaya para pemimpin agama dunia, yang mewakili kepedulian internal dari pikiran dan hati nurani, bekerja secara kooperatif dan hormat. (Moon, 2000) Kehadiran pemimpin pembawa damai sangat dinantikan, dirindukan untuk dunia yang lebih baik, khususnya dalam pembangunan hubungan yang baik antarumat beragama.

\section{Upaya-upaya Pemimpin dalam Menciptakan Perdamaian}

Upaya-upaya pemimpin pembawa damai dalam menciptakan perdamaian adalah: Pertama, pengajaran tentang perdamaian. Guna mencapai perdamaian, perlu diajarkan perdamaian. (Sudarmanto, 1989) Urgensi suatu teologi perdamaian adalah masalah perdamaian. Anti kekerasan itu mengacu pada campur tangan aktif dalam cinta kasih pada situasi konflik. Tindakan aktif sebagai karya konstruktif bagi keadilan dan penciptaan perdamaian. (Sudarmanto, 1989)

Mengajarkan, membawa, dan menciptakan perdamaian berarti berupaya mencari satu atau banyak jalan yang dipadukan tanpa menolak tanggung jawab seseorang terhadap hak orang lain. Umat beriman menaklukkan kekerasan dengan cinta kasih. Shalom berarti kepenuhan hidup sebagai buah cinta kasih. Orang Kristen harus bekerja sama dengan semua orang yang cinta damai dalam membela perdamaian. (Sudarmanto, 1989)

Kedua, tindakan perdamaian. Setiap pemimpin perlu mengupayakan perdamaian agar tercipta keharmonisan dalam kehidupan masyarakat dengan (Fisher) 1) Menciptakan perdamaian, yaitu bentuk-bentuk intervensi untuk mengakhiri permusuhan dan menghasilkan kesepakatan melalui salah satunya dengan diplomasi. 2) Menjaga perdamaian, yaitu memantau dan menegakkan kesepakatan. 3) Menggalang perdamaian, yaitu melaksanakan program-program yang dirancang untuk mengatasi penyebab konflik dan penderitaan dari masa lalu dan meningkatkan kestabilan dan keadilan. Memelihara perdamaian merupakan tugas yang tidak mudah ketika kecenderungan ketidakadilan marak di mana-mana. Berbagai ketegangan dan konflik yang mengatasnamakan agama telah memakan korban. Perdamaian sejati di antara umat manusia tidak akan tercapai kalau tidak ada perdamaian di antara penganut agama-agama yang berbeda. (Aritonang \& Gultom)

Ketiga, mengembangkan gaya hidup (life style) pembawa damai. Gaya hidup menjadi seorang pendamai, yaitu: rendah hati (Luk. 2:12-14), mengutamakan orang lain, inisiatif mengupayakan damai, menjadi terang, tidak menyimpan kesalahan orang lain, berpikir positif, menikmati perbedaan, menjaga kebenaran dalam kasih, menyelesaikan masalah secepat mungkin, berdoa sungguh-sungguh. (Palmer, 1990) Keempat, membangun jejaring perdamaian. Pemimpin pembawa damai perlu menjalin jejaring (networking) yang saling membantu untuk menciptakan proses perdamaian dan mencegah atau meminimalisasi konflik agar tidak terjadi kekerasan. Membangun kerjasama, gotongroyong lintas agama untuk memupuk persatuan, kesatuan dan perdamaian. Selain itu, menyadarkan masyarakat bahwa hidup bersama itu penting dan perdamaian itu indah (Qurtuby).

\section{Karakter Pemimpin Pembawa Damai}

Karakter berasal dari istilah kharax, kharassein yang berarti membuat tajam atau dalam. Karakter berarti tabiat, watak, sifat kejiwaan, akhlak atau budi pekerti yang membedakan seseorang dengan yang lain (Poerwadarminta, 2006). Karakter adalah kumpulan dari nilai, sikap, dan tindakan seseorang. Karakter seorang pemimpin menentukan perbuatan yang dilakukannya. Karakter terletak pada jiwa, hati, dan gaya 
pemimpin. Karakter adalah produk dari hati yang benar. Dan dari hatilah mengalir keberanian moral, kesadaran, keteguhan, belas kasihan (Bowling).

Karakter menunjukkan moral seseorang (Bowling). Karakter merupakan jumlah total (Tim Elmore) dari disiplin diri (kemampuan untuk melakukan apa yang benar, apapun risikonya), nilai-nilai inti (prinsip yang pemimpin jalani yang memampukan untuk memiliki pegangan moral), kesadaran identitas (gambaran diri yang realistis berdasarkan maksud tujuan menciptakan manusia), dan keamanan emosional (kapasitas untuk menjadi stabil secara emosional dan konsisten).

Karakter adalah sifat, hakikat, dan eskpresi kepribadian seseorang yang dinyatakan melalui perkataan dan tingkah laku dalam lingkungan atau konteks di mana ia hidup. (Tomatala, 2001) Karakter adalah sifat-sifat kejiwaan, akhlak, budi pekerti, tabiat, dan watak. (https://kbbi.kemdikbud.go.id/entri/karakter) Karakter adalah sebuah kekuatan. Selain itu, karakter merupakan landasan dan jaminan untuk pemimpin yang tahan uji di masa-masa sulit dalam menyongsong masa depan yang penuh dengan kesuksesan. (Ndoen, 2012)

Karakter dapat menentukan penampilan citra diri pemimpin. (Sukri, 2013) Kunci keberhasilan pembentukan karakter ditentukan oleh tekad, kepercayaan, dan kerelaan diri untuk dibentuk. Dengan memahami pembentukan karakter sejak dini, maka generasi masa depan lebih baik, lebih termotivasi dan penuh sukacita. Karakter adalah proses akhir dengan nilai abadi.

Karakter menentukan identitas diri seseorang. Perkembangan karakter kepemimpinan membutuhkan disiplin diri, sebab melibatkan hati dan bukan hanya kebiasaan. (Hayford, 2002) Karakter berkaitan dengan pengabdian, melibatkan transformasi dan inspirasi. Karakter melibatkan Roh Kudus yang bekerja dalam batin seseorang. Karakter berkaitan dengan kekudusan hidup, keterbukaan, dan ketulusan di depan orang lain. Seseorang yang berkarakter baik memiliki konsistensi dan integrasi, atau penyatuan antara komponen dalam mekanisme internalnya. (Chandra, 2000) Pemimpin yang berkarakter baik atau berkualitas baik adalah orang yang memiliki keserasian antara gambar diri, tata nilai, kebutuhan, peran, ambisi, dan faktor-faktor turunannya seiring dengan gambar diri serta tata nilainya, dan sebaliknya. Kristus adalah rujukan bagi orang yang hidup dalam karunia-Nya dalam proses untuk memiliki karakter yang baik.

Pemimpin yang bertumbuh, profesional, dan unggul harus didukung enam pilar karakter. (Chen, 2011) Enam pilar karakter itu adalah: trustworthiness (jujur, dapat dipercaya, pejuang kebenaran), responsibility (disiplin, tanggung jawab, berpikir sebelum bertindak, siap terhadap konsekuensi dari pilihan atau keputusannya), respect (menghargai sesama, memperlakukan orang lain dengan hormat), fairness (sesuai peraturan yang berlaku, bersedia untuk berbagi, berpikir positif terhadap orang lain), caring (ramah, pemaaf, peduli sesama, membantu orang lain yang kesulitan), citizenship, (menjadi anggota masyarakat yang mematuhi hukum dan aturan yang berlaku, menghargai pemerintah, berperan aktif dalam komunitas atau masyarakat, dapat bekerjasama dengan baik).Karakter memiliki tiga bagian yang saling berhubungan, yaitu moral knowing (knowing the good), moral feeling (desiring the good), dan moral behavior (doing the good). (Yahya, 2017) Dalam karakter terdapat nilai operasional dan nilai praktikal. Jadi, karakter dapat didefinisikan artinya dan dipraktikkan dalam kehidupan sehari-hari.

Tujuan pengembangan karakter adalah pemimpin yang berpusatkan pada Kristus dan kebenaran (Mat. 9:36; Yoh. 13:1-20, 34-3). Pemimpin yang berpusat pada Kristus adalah pemimpin yang tunduk dan memuliakan Allah. Pemimpin yang baik memiliki karakter yang baik, yang dapat mengendalikan perilaku dan kinerja kepemimpinannya. Karakter yang baik terwujud dan terlihat dari kebiasaan, sikap, perilaku yang terikat pada kebenaran, memantapkan relasi sosial, kinerja dan penyelesaian. 
Mengenai karakteristik Yesus Kristus sebagai pembawa damai meliiputi: kasih (mengasihi), pengampunan (mengampuni), suka damai (pendamai), adil, dan solidaritas.

\section{Kasih (Mengasihi)}

Kasih dalam bahasa Yunani adalah "agape" yang berarti memperhatikan dan mencari yang terbaik bagi orang lain tanpa alasan pamrih atau mengharapkan imbalan. Kasih adalah buah roh yang utama. Kasih merangkul dan melibatkan seluruh buah Roh lainnya. Kasih dapat dimulai dari atau dalam wujud yang kecil, misalnya tetap perhatian kepada saudara-saudara dengan cara memperhatikan, mendoakan, memberi nasihat dan lain seb

Yesus merupakan sosok yang mengasihi, yang terjangkau oleh manusia, adem, sejuk, dan damai, tapi juga memberi kehangatan, yang tersenyum dan menangis bersama tangisan dan duka, memberi semangat dalam kelesuan, dan membangkitkan pengharapan dalam keputusasaan. (Kusmaryanto) Cinta kasih membangun perdamaian kalau orang merasa kebutuhan akan orang lain sama seperti dirinya sendiri dan membagikan apa yang di miliki dengan orang lain, khususnya nilai akal budi dan roh yang dia miliki.

Yesus Kristus adalah wajah belas kasih Bapa (Luk. 6:36), artinya Yesus adalah sosok yang mengayomi dan memberi kedamaian bagi mereka yang berada di dekat-Nya. Belas kasih dan mengampuni adalah tanda kebesaran dan kemuliaan hati. (Thomas Aquinas) Dalam Perjanjian Baru, Allah penuh belas kasihan (Luk. 14:11-32). Belas kasih Yesus adalah sumber kegembiraan, ketenteraman, dan damai. Kasih merupakan tindakan yang tertinggi dan terakhir yang dengannya Yesus datang untuk menjumpai manusia.Kasih adalah hukum dasar yang tinggal dalam hati setiap manusia yang mencari jalan kehidupan dengan tulus ikhlas.Hati Yesus tergerak oleh belas kasih kepada manusia yang mengalami kemalangan (Mat. 9:36; 14:14). Kasih selalu lebih besar daripada semua dosa. Tidak ada yang mampu membatasi kasih Kristus pada manusia.Yesus lebih memilih kasih (misericordia) daripada memakai kekerasan.

Perintah Yesus menempatkan kasih kepada Allah dan sesama manusia sebagai yang penting, sejajar, dan sama besarnya (Mat. 22:37-39; Mrk. 12:30-31; Luk. 10:27). Universalitas perintah Yesus untuk mengasihi sesama manusia terdapat dalam perumpamaan orang Samaria yang baik hati (Luk. 10:25-37). Yesus juga mengajari untuk mengasihi musuh (Mat. 9:11-12; Luk. 6:27-28). Standar moral cinta kasih Yesus sangat tinggi. Hal ini berlaku bagi para pengikutnya (Mat. 5:46-47; Luk. 6:32-33).

Kasih tidak terbatas pada sejumlah kelas atau kelompok manusia tertentu, sebaliknya kasih melampui batas-batas sosial dan agama, serta memandang orang lain sebagai manusia yang harus dikasihi. (Nurcholis, Alamsyah, Dja'far, 2015) Kasih kepada manusia tidak akan memihak atau berat sebelah (Luk. 10:29-37; Yak. 2:9). Universalitas kasih dalam dikatakan Yesus Kristus dalam Matius 5:43-45.

Sikap Yesus yang radikal menuntut cinta kasih terhadap musuh dan menolak kekerasan. Yesus mengajarkan untuk mengasihi musuh dan berdoa bagi mereka yang menganiaya (Mat. 5:44). Gaya hidup dan hasrat Yesus adalah berjuang terhadap keadilan, kepedulian-Nya terhadap kaum yang tertindas dan terbuang menunjukkan kasih-Nya yang begitu besar. Yesus mengajarkan prinsip mengasihi musuh, karena Dia tahu bahwa kasih akan disempurnakan dalam kehidupan orang percaya yang bersedia melayani orang-orang yang menyakiti mereka, sehingga dapat mengatasi pencobaan sakit hati. (Zoschak, 2003)

Motivasi dasar ajaran Yesus adalah cinta kasih. (Sudarmanto, 1989) Cinta kasih memiliki arti: Pertama, cinta kasih tidak akan membiarkan orang yang dikasihi menderita. Ia tidak akan tahan melihat orang lain mengalami penderitaan. Kedua, apabila orang yang dicintai mengalami ketidakadilan, disakiti, dirampas haknya, diperdaya, dibohongi, maka cinta kasih sejati mendorong orang untuk berbuat sesuatu dan berjuang sekuat tenaga. 
Cinta kasih sejati akan menuntut keadilan terhadap pengakuan harkat dan martabat manusia. Inilah yang dilakukan Yesus. Ia adalah potret Sang Revolusionist yang anti kekerasan (non-violent). Kasih meruntuhkan tembok-tembok pemisah dan membangun persekutuan dan persaudaraan. Dengan kasih memungkinkan manusia hidup damai sejahtera. Yesus mempraktikan love is action, cinta kasih adalah tindakan. Yesus merupakan Wacana Hidup.Yesus memerintahkan kepada pengikut-Nya untuk mengasihi sesama. Sesama di sini termasuk musuh. Musuh merupakan sasaran kasih. (Betz, 1995) Yesus dalam Golden Rules melarang pembalasan dan penghakiman (Mat. 7:1-12). Meskipun Yesus masuk dalam situasi di mana kekerasan merajalela, namun Dia tidak ikutikutan atau terpengaruh untuk melakukan tindakan kekerasan.

\section{Mengampuni}

Pengampunan adalah gerak meninggalkan masa lalu dan melupakan pengharapan akan terjadinya hal yang lebih baik di masa lalu. (Luskin, 2007) Pengampunan berkaitan dengan orang yang disakiti dengan tidak adil yang secara sukarela menghentikan kemarahan, dendam, sakit hati, kebencian kepada orang yang telah bersalah kepadanya dalam konteks luka yang dalam, tidak adil, dan bersifat personal. (Enright, 2001) Pengampunan akan mempersatukan manusia, menyembuhkan luka, menghapus kebencian dan dendam yang terjadi karena perbuatan yang salah. (Luskin, 2007)

Mengampuni merupakan nilai penting dalam terjadinya perdamaian. Mengampuni adalah keputusan dan pembuka jalan bagi perdamaian. (Lincoln, AmaLee, 2007) Beberapa ciri pengampunan: Kristus yang bisa mengampuni, pengampunan tertuju pada umat manusia, pengampunan datang dari kekudusan Allah dan berdampak pembaharuan, pengampunan membawa kehidupan dan mengakhiri segala macam hukuman.

Dasar dan tujuan pengampunan adalah kasih (Yoh. 3:16; 1 Yoh. 3:1; 4:8). Ketika Kristus mengasihi, Dia memberi diri-Nya sendiri (Yoh. 15:13). Dengan kasih itu menggerakkan untuk berbuat caritas Christi urget nos. Tidak ada kasih yang sempurna kalau tidak bisa mengampuni, karena pengampunan adalah perwujudan kasih. (Lincoln, AmaLee, 2007) Meskipun manusia yang bersalah dan memerlukan pengampunan, tetapi Yesus berinisiatif untuk mengampuni dan menyelamatkan manusia (Mat. 18:12; Luk. 19:10). Apabila inisiatif datang dari Yesus, yang tidak bersalah dan mengusahakan pengampunan, maka penyelesaiannya akan tuntas, sebab yang dilukai sudah memutuskan untuk mengampuni, sehingga tidak ada masalah lagi. Pengampunan dari Yesus akan efektif dan mengena secara personal jika ada pertobatan dari pihak yang berdosa. Orang yang tidak mau bertobat tidak akan mengalami pengampunan.

Yesus dengan kasih yang besar datang ke dunia untuk menebus manusia. Penebusan dilaksanakan dengan pengampunan. Jika Yesus tidak mengampuni, maka tidak aka nada harapan bagi manusia. Yesus sebagai Allah mampu mengampuni manusia (Mat. 6:14; 9:2, 6; Mrk. 2:5; Luk. 7:48). Keselamatan manusia tergantung pada pengampunan dari Kristus. Jadi penyelamatan manusia bukan karena jasa manusia, melainkan bahwa Yesus maha pengampun.

Yesus adalah Pribadi yang suka mengampuni. Sikap penuh kasih terhadap musuhmusuh-Nya. Yesus menantang dan memberi makna terdalam dari pengampunan dan kenyataan yang penuh daya yang terdapat dalam peristiwa pengampunan (Luk. 23:33-43). (Septemmy E. Lakawa) Pengampunan Yesus menjadi penuh daya karena pengampunan itu ditawarkan justru oleh korban pada saat Ia sedang mengalami kekerasan itu sendiri. Tujuan kedatangan Yesus ke dunia untuk menyelamatkan manusia dari dosa (Mat. 1:21), memanggil para pendosa dan mengampuninya (Mat. 9:13; 26:28). Pengampunan Yesus Kristus membawa kesembuhan, perubahan spiritual, dan kelepasan. Pengampunan Yesus Kristus memulihkan kembali status manusia sebagai anak-anak Allah. 
Pengampunan yang menantang secara bersamaan keluarnya suara dan aksi pertobatan pelaku kekerasan. Inilah salah satu kejutan teologis dari peristiwa salib, yaitu salib sebagi kisah teror ditransformasi (diubah) menjadi sebuah kisah pengampunan dan pendamaian (Mat. 26:28). Peristiwa salib memungkinkan manusia melihat wajah Allah yang tanpa kekerasan. Wajah Allah yang demikian menantang manusia untuk melihat kembali jati diri dan memaknakan identitas manusia dalam realitas kekerasan di tengahtengah hidup manusia, sekaligus menilai ulang jalan dan cara yang telah manusia pilih ketika berhadapan dengan kekerasan.

Di atas kayu salib, Yesus berdoa dan mengampuni orang-orang yang melakukan tindakan kekerasan terhadap-Nya (Luk. 23:34). Dan setelah kebangkitan-Nya, Yesus mengucapkan "damai sejahtera" (Yoh. 20:19). Kebangkitan Kristus menyatakan bahwa Allah mengasihi manusia. Damai Kristus membungkus kehidupan manusia, bahkan penderitaan dan maut yang paling kejam sekalipun.

Alkitab menjelaskan perintah Yesus yang mungkin bagi dunia terlihat aneh dan berat. Yesus telah memerintahkan agar umat-Nya mengasihi dan mengampuni musuh, berbuat baik kepada orang yang membenci dan mengutuk, serta berdoa bagi orang yang menghina atau mencaci maki (Mat. 5:44; Luk. 6:27-28).

Pengampunan tidak bergantung kepada apa yang dilakukan orang lain seperti Yesus Kristus yang mengampuni orang lain walaupun mereka tidak menyesali perbuatannya (Luk. 23:34). Dengan mengampuni berarti menyerahkan kepada Allah untuk menuntut pertangungjawaban orang yang melakukan kejahatan. Pengampunan membebaskan orang percaya dari amarah dan kepahitan. Pengampunan juga menjadi jalan Allah mengampuni orang percaya (Mat. 6:14-15; Mrk. 11:25). Pengampunan menunjukkan penghayatan orang percaya akan pengorbanan Yesus Kristus (Mat. 18:21-35). Pengampunan menjadi jalan orang percaya untuk memulihkan hubungan dengan orang yang bersalah. Pengampunan dapat mengubah orang yang bersalah.

Yesus Kristus memberi perintah untuk saling mengampuni dalam kehidupan (Mat. 18:22, 35; Mrk. 11:25; Luk. 6:37; 17:3). Mengampuni bukan berarti membiarkan kejahatan atau merestui dan melegalkan kejahatan, tetapi tidak memperhitungkan kesalahannya. (CB. Kusmaryanto) Jika orang percaya sudah memutuskan untuk mengampuni, ini berarti dapat mengatasi kecenderungan instigtif dan diganti dengan pola pikir Yesus yang sudah mengalahkan instinc orang percaya (Mat. 18:21-35). Semua pertengkaran, peperangan, perselisihan, pertentangan, dendam, iri hati dapat disembuhkan secara permanen melalui kasih dan pengampunan.

Orang percaya harus mengampuni karena jika tidak mengampuni maka persembahannya tidak akan berkenan di hadapan Allah (Mat. 5:23-24).(Budi) Jika orang percaya tidak mau mengampuni, maka Bapa di sorga juga tidak akan mengampuni orang percaya (Mat. 6:14-15; Mrk. 11:25). Pengampunan akan memperbaiki kesalahan dan menyelesaikan masalah. Orang percaya tidak boleh membalas, karena pembalasan adalah sepenuhnya hak Allah. Orang percaya harus bersedia mengampuni orang atau pihak yang bersalah.(Anderson) Pengampunan itu penting karena Allah menghendaki umatnya, termasuk pemimpin Kristen untuk mengampuni. Dengan mengampuni maka akan terhindar dari jerat Iblis. Pengampunan merupakan prosedur standar dalam hubungan antara sesama orang Kristen.

\section{Suka Damai}

Istilah damai sejahtera dalam bahasa Yunani adalah"eirene" yang memiliki arti ketenangan hati dan pikiran yang berlandaskan pengetahuan bahwa semua beres. Istilah "eirene" juga berarti kesejahteraan, kepenuhan, harmoni.(Arrington) Damai sejahtera adalah ciri-ciri dari anak-anak Allah. Damai sejahtera berasal dari Allah dan merupakan 
pemberian Yesus Kristus (Yoh. 14:27). Yesus Kristus adalah Juru Damai yang Agung. Dia membawa damai sejahtera, yaitu membangun hubungan yang benar anntara Allah dengan umat manusia melalui darahnya di atas kayu salib.

Yesus melaksanakan kehendak Bapa untuk menyelamatkan manusia, sehingga diperdamaikan dengan Allah (Yoh. 3:16). Karya keselamatan tertuju kepada pendamaian segala sesuatu dalam diri Kristus.Saat di kayu salib, Yesus berkata, "Ya Bapa, ampunilah mereka, sebab mereka tidak tahu apa yang mereka perbuat." (Luk. 23:34). Ucapan Yesus sungguh bertolak belakang dengan kebencian, kepahitan, dan ketakutan yang ditunjukkan oleh salah seorang penjahat yang disalibkan bersama Dia. (Robert E. Leland 2004) Yesus mengampuni orang yang melakukan kekerasan terhadap Dia karena: mereka tidak tahu apa yang mereka perbuat alias buta rohani (Yoh. 16:2b), Kristus tahu bahwa dibalik pengkhianatan dan kebencian terhadap diri-Nya, Allah justru sedang menyelesaikan rencana-Nya yang besar bagi manusia yaitu penebusan.

Allah ingin perdamaian antara Diri-Nya dan umat manusia, karena itu Dia menyediakan kedamaian melalui kematian Anak-Nya.Yesus memberi kedamaian di antara umat manusia di atas kayu salib. Ketika dunia mengatakan bencilah musuh-musuhmu, kutuklah orang yang menganiaya kamu, batasi pengampunan, balaslah kesalahan, ternyata Yesus mengajarkan hal yang berbeda. Ia mengajarkan kasihilah musuhmu (Mat. 5:43-44), berkati orang yang menganiaya kamu, mengampuni tanpa syarat (Mat. 18:21-22), jangan membalas dendam.

Yesus melakukan karya pendamaian atau rekonsiliasi. Rekonsiliasi berkaitan dengan dihilangkannya permusuhan dan pemulihan keharmonisan dalam suatu hubungan. Artinya adalah tembok yang memisahkan pihak-pihak yang bermusuhan telah dibongkar, keretakan hubungan sudah dipulihkan.Allah mengambil prakarsa untuk menjangkau orang berdosa melalui pengorbanan Yesus Kristus di kayu salib.Kematian Yesus Kristus menyediakan pemulihan hubungan antara Allah dan manusia serta kerusakan yang terjadi di Taman Eden pada waktu Adam berbuat dosa.

Yesus mengajarkan tentang perdamaian, yaitu membersihkan dunia ini dari berbagai macam kedurhakaan, kejahatan, dan kekerasan. Memang, konsep perdamaian menurut orang Yahudi berbeda dengan ajaran Yesus.Orang Yahudi merindukan damai secara politis, yaitu diusirnya penjajah dari Israel, sehingga tidak ada penjajahan, perang, dan penindasan lagi. Tentu ini sangat berbeda dengan damai yang ditawarkan Yesus.Damai sejati merupakan pencapaian kebenaran, ketenangan dalam hati (batin) karena orang memiliki hubungan yang intim dan bersih dengan Allah yang kudus. Damai dapat dialami jikalau seseorang datang kepada Yesus, Sang Raja Damai seperti dalam firman yang berkata "Berbahagialah orang yang membawa damai, karena mereka akan disebut anak-anak Allah" (Mat. 5:9).

Ketika sedang mengajar orang-orang di bukit, Yesus berkata, "Janganlah kamu melawan orang yang berbuat jahat kepadamu, melainkan siapapun yang menampar pipi kananmu, berilah juga kepadanya pipi kirimu" (Mat. 5:39). Hal ini merupakan pedoman dasar dari nilai menolak kekerasan. Kekerasan dilawan dengan kekerasan hanya akan menimbulkan konflik yang berkepanjangan. Yesus ingin agar pengikut-Nya menolak kekerasan, dan mengantinya dengan tindakan kasih.

Dalam Perjanjian Baru Yesus tampil dengan warna lain. Yesus justru menolak bekerjasama dengan orang Zelot yang menggunakan cara kekerasan bagi pembebasan Yahudi dari penjajahan Romawi (Lukas 9:58). Zelot adalah golongan yang memeluk kekerasan sebagai sarana utama pembebasan dari Roma. Zelot berarti a person who shows Zeal. Golongan Zelot menunjukkan kesungguhan dan kefanatikan untuk mencapai suatu tujuan. Kelompok teroris mengijinkan pembebasan dari Romawi beserta kolaborator Yahudi dengan jalan kekerasan. 
Yesus mengajarkan untuk mengasihi seteru (Mat. 5:44-45). Yesus mencegah para pemuka Yahudi merajam wanita yang ketangkap basah sedang berzinah (Yoh. 8:3-11). Bagi jemaat perdana, Yesus dikenal sebagai tokoh gerakan nirkekerasan yang menentang segala macam bentuk praktik kekerasan. Yesus adalah tokoh yang mengajari pengikut-Nya untuk tidak membalas dendam.Sebaliknya, pengikut-Nya diajar untuk menjadi pembawa damai bagi dunia.

\section{Adil}

Yesus menolak sikap legalisme dan ortodoksi kaku dan meneguhkan semangat kebebasan yang bertanggung jawab. Yesus menentang ketidakadilan sosial (Mat. 6:33) dan sistem politik yang merendahkan martabat manusia lewat denominasi yang tidak adil. (Gruchy, 2003) Yesus peduli keutuhan umat dan kebebasan, serta gigih menentang ketidakadilan. (Yoder, 1984)

Yesus adalah Sang Pendamai yang membebaskan. Ia penuh dengan urapan untuk memberi pembebasan bagi orang miskin, tawanan, dan orang-orang yang tertindas (Luk. 4:18-19). Ia memberi kekuatan bagi pengikut-Nya untuk berjuang bagi keadilan. Yesus membebaskan seseorang dari keterikatan harta dan kekayaan (Luk. 19:1-10). Yesus juga membebaskan pengikut-Nya dari rasa takut, dendam, benci dengan pengampunan (Luk. 23:33-43). Selain itu, Yesus juga membebaskan dari belenggu ideologis, contohnya orang Samaria yang baik (Luk. 10:25-37). Yesus mengutuk kekerasan dan mendorong pengikutNya untuk membawa perdamaian. (Williard M. Swartley 1992) Yesus menunjukkan perdamaian dengan menaiki seekor keledai muda ke Yerusalem (Mrk. 11:1-10). Ia menolak pengharapan Mesias militer yang masuk ke kota Daud dengan kuda-kuda dan kereta-kereta. Sebaliknya, ia berpaling pada pengharapan Zakharia akan raja yang akan datang. (Desjardins, 1997) Pada saat penangkapan Yesus, Ia tidak melawan dengan kekerasan (Luk. 22:37, 49). Panggilan perdamaian di dalam diri Yesus sangat kuat. Meski ajaran Yesus mengajarkan untuk mengasihi musuh, tentu bukan berarti bahwa Yesus menolak pertentangan. Yesus juga menolak kultur kekerasan agama yang biasanya berupa aturan mengikat yang membuat orang tertindas. (Budi Setiawan: 2009) Yesus tidak menganjurkan tindakan militer dan kekerasan apa pun untuk melawan pemerintahan Romawi, tetapi berbicara dengan istilah-istilah positif tentang kekuatan bala tentara Romawi dan perdamaian (Mat. 5:9, 41; 22:21). Perdamaian dengan Allah harus menjadi nyata dalam perdamaian dengan sesama dengan cara berlaku adil, memberi kompensasi atas ketidakadilan yang sudah dibuat.

Tujuan Yesus terwujud ketika semua umat manusia berada dalam, menikmati iklim keadilan dan kesejahteraan. (Yewangoe, 2009) No peace without justice, no justice without forgiveness. Perdamaian memang erat dengan keadilan. Keadilan erat kaitannya dengan pengampunan. Tidak ada damai tanpa keadilan, tidak ada keadilan tanpa pengampunan.

Yesus sebagai Pemimpin mengarahkan matanya dengan teliti terhadap ketidakadilan, dan akan berjuang untuk terwujudnya keadilan.(Lack) Pemimpin tidak diam ketika terjadi pelanggaran dan segera meluruskan segala macam kekeliruan. Peringatan dari pemimpin memiliki konsekuensi jika tidak dilaksanakan dengan baik. Pemimpin berani menegakkan hukum dan aturan agar tidak diabaikan oleh bawahan. Apabila pemimpin tidak tegas, maka kepemimpinannya akan ternoda dan tidak disegani lagi. Pemimpin harus bersikap adil terhadap bawahannya.

\section{Solidaritas}

Beberapa bukti solidaritas Yesus terhadap manusia adalah: Pertama, Yesus hadir ke dunia untuk merasakan semua yang dirasakan manusia. Yesus lahir dalam kemiskinan, hidup dalam keprihatinan, menderita, dan mati dalam kehinaan. Yesus mengidentifikasi 
diri-Nya dengan manusia yang hina, menderita dan terkutuk. Ia hadir ke dunia memberi kebebasan dan kelepasan. Solidaritas-Nya berdasarkan cinta kasih-Nya kepada manusia. Wujud solidaritas-Nya dalam perhargaan terhadap manusia sebagai makhluk yang bermartabat dan rela mengorbankan nyawa-Nya untuk menyelamatkan manusia (2 Kor 5:15). Kedua, Yesus merobohkan tembok ekslusivisme, keegoisan, dan kesombongan. Eksklusfivisme mengabaikan kemanusiaan. Yesus merobohkan tembok pemisah antara yang kaya dan miskin dengan mengajarkan bahawa orang yang miskin di hadapan Allah adalah orang yang berbahagia karena merekalah yang memiliki surga. Selain itu, orang yang hidup dalam aksih, yaitu bermurah ahti adalah orang yang berbahagia, karena mereka akan mendapat kemurahan Allah. Solidaritas dalam kasih adalah wujud nyata kehidupan sesungguhnya. Bukan hanya teori belaka. Yesus membasuh kaki murid-murid-Nya, menyembuhkan orang sakit, membangkitkan orang mati, memberi makan orang banyak dan lain sebagainya. Yesus juga memberi paradigma baru tentang persaudaraan melalui cerita orang Samaria yang baik hati (good Samaritan). Yesus mengajarkan murid-muridNya untuk hidup dalam solidaritas yang murni, "Segala sesuatu yang kamu lakukan untuk salah seorang dari sauddara-Ku yang paling hina ini, kamu telah melakukannya untuk Aku” (Mat. 25:40b).

Karya Kristus menunjukkan dua kebenaran penting yaitu solidaritas dan identifikasi. (Sudarmanto, 2014) Dalam solidaritas, Yesus merendahkan diri dari yang mulia menjadi kecil dan lemah, masuk dalam kesakitan dan penderitaan manusia. Yesus Kristus menyembuhkan, memberi makan yang lapas, mengampuni orang berdosa, membangkitkan orang mati, dan menjadi Sahabat yang baik yang rela mati bagi manusia. Dalam identifikasi diri, Yesus menjadi manusia dan memasuki dunia manusia yang Dia layani. Prinsip solidaritas dan identifikasi diri ini menjadi dasar kristologis bagi hubungan multikultural, multietnis, dan multireligi.

Yesus Kristus melihat ada banyak orang yang tidak toleran. Orang Yahudi dan orang Samaria saling membenci (Yoh. 4:9). Wanita dianggap lebih rendah daripada pria. Dan, pemimpin agama Yahudi menghina rakyat jelata. (Yoh. 7:49) Yesus baik, sabar, dan toleran karena ia datang bukan untuk menghakimi, tapi untuk menyembuhkan orang-orang secara rohani (Luk. 15:2). Motivasi utama Yesus adalah kasih (Yoh.3:17; 13:34), karena kasih membuat hidup menjadi toleran, memaklumi, dan memahami orang lain dengan segenap hati.

Yesus menasihati pengikut-Nya untuk bertoleransi yaitu dengan saling mengasihi (Yoh. 13:34), hidup harmonis dan damai dengan sesama, sabar, ramah, lemah lembut terhadap orang lain, bersukacita dalam kebenaran, mengatasi perbedaan dengan hikmat Tuhan, menanggung beban sesama, dan memperhatikan kebutuhan orang lain.

\section{Dampak Kepemimpinan Yesus Kristus Sebagai Pembawa Damai}

Murid-murid Yesus adalah orang-orang yang telah dipanggil, dipilih, diajar, dilatih, dan diutus untuk membawa damai sejahtera bagi bagi semua orang. Dampak dari kepemimpinan Yesus Kristus sebagai pembawa damai adalah: Pertama, terciptanya perdamaian antara Allah dan manusia, melalui karya pendamaian Kristus. Kedua, penghentian kekerasan (Mat. 5:24-25; Mrk. 9:50; Luk. 2:14). Murid-murid Kristus memberitakan Injil dengan kasih. Mereka membagi damai sejahtera Kristus bagi banyak orang. Ketiga, regenerasi dan suksesi pemimpin pembawa damai. Murid-murid dan pengikut Yesus meneladani-Nya dengan menjadi pemimpin pembawa damai.

\section{Resolusi Konflik}

Resolusi konflik adalah sebuah situasi suatu kerangka teoretis dan praktik yang bertugas untuk mengurangi dampak kerusakan yang terjadi akibat konflik, membuat 
perjanjian untuk menyelesaikan dan mengakhiri konflik dan kekerasan. (Wallensteen, 2007) Puncak konflik merupakan hal yang dianggap sebagai tantangan dalam konflik, sering kali dengan penekanan pada apa yang baru saja terjadi. Puncak konflik sering diidentifikasikan sebagai masalah yang sedang dihadapi, yakni kandungan konflik. Adapun lembah konflik merupakan kegagalan atau ketidakmampuan dalam menegosiasikan solusi yang memuaskan. (Lederach, 2005)

Resolusi konflik memiliki keuntungan jika dipilih menjadi pendekatan penyelesaian masalah. Keuntungan tersebut adalah: pihak-pihak yang terlibat konflik mengendalikan emosi, memiliki keterampilan dalam pemecahan konflik secara konstruktif di masa yang akan datang, membangun iklim yang positif dan kondusif, menghargai perbedaan dan keberagaman, toleransi meningkat, meningkatkan kerjasama, menciptakan perasaan damai dalam hidup bersama, meningkatkan rasa hormat, pengertian, perhatian, dan konflik terselesaikan.

Dalam Alkitab dapat dipelajari resolusi yang dilakukan Yesus sebagai respon-Nya terhadap konflik. (Lawson, 2009) Pertama, Yesus adalah seorang pendengar yang hebat. Ia mampu memahami kata-kata dan pikiran yang sedang diekspresikan. Sebagai contoh, pertemuan Yesus dengan Nikodemus (Yoh. 3:1-21). Yesus dapat membaca apa yang tersirat dan melihat pertanyaan yang akan diajukan. Kedua, pengendalian diri. Kemarahan Yesus selalu terkendali dan seimbang dengan masalah yang dihadapi. Ketiga, menyambut konflik. Yesus tidak mundur dari situasi konflik.Dia menyambut konflik sebagai kesempatan baik untuk mengajarkan kebenaran. Keempat, pengampunan dan adil. Yesus memperluas prinsip keadilan yang tercantum dalam hukum (mata ganti mataa, gigi ganti gigi) dengan perintah untuk memberikan pipi yang lain (Mat. 5:38:42). Yesus melarang balas dendam. Yesus memprioritaskan pengampunan.

Kelima, sabar. Yesus pernah marah kepada murid-murid-Nya, karena kelambatan mereka untuk belajar dan memiliki iman, namun Yesus tetap sabar kepada mereka. Keenam, menarik diri.Yesus pernah menarik diri atau menyingkir dari keramaian saat konflik berkembang.Hal ini menunjukkan bahwa Dia sensitif terhadap mereka yang menjadi marah dan tidak bisa diajak berdiskusi secara rasional.Ketujuh, berani menghadapi.Meski dihina dan dihindari, tetapi pukulan spiritual, emosial, dan fisik yang Dia terima, tidak membelokkan-Nya dari tugas dan konflik yang sering melibatkanNya.Yesus tidak menghindari penderitaan.

Kedelapan, dialog. Dalam Matius 18:15-17, Yesus juga mengajarkan bagaimana melakukan resolusi konflik. Menurut ayat ini, dalam konflik yang melibatkan dosa secara faktual, maka harus ditangani secara langsung bertatap muka (face to face). Tetapi jika belum tuntas atau selesai, maka perlu ditangani sekelompok kecil. Namun jika belum tuntas juga baru dihadapkan ke gereja. Di sisi lain, Lukas 17: 3-4 menyatakan "Jagalah dirimu! Jikalau saudaramu berbuat dosa, tegorlah dia, dan jikalau ia menyesal, ampunilah dia. Bahkan jikalau ia berbuat dosa terhadap engkau tujuh kali sehari dan tujuh kali ia kembali kepadamu dan berkata: Aku menyesal, engkau harus mengampuni dia." Pengampunan akan memulihkan dosa dan menyelesaikan konflik. Pengampunan tidak akan memperpanjang masalah dan mencegah masalah menjadi besar. Pengampunan membuat hati menjadi tenang dan damai.

\section{METODE PENELITIAN}

Dalam penelitian ini, menggunakan paradigma naturalistik yaitu, penelitian mengenai pemahaman terhadap suatu realitas yang tampak pada pengalaman seseorang atau sekelompok orang. Sedangkan pendekatan yang digunakan adalah pendekatan kualitatif yang dibangun di atas landasan filsafat atau paradigma fenomenologi dengan menggunakan karakteristik penelitian alamiah, realitas bersifat terbuka, kontekstual, 
jamak, menyeluruh, dan komunal. Penelitian ini menggunakan metode fenomenologi, yaitu peneliti berusaha memahami perilaku manusia dari segi kerangka berpikir maupun tindakan orang-orang itu. Data dikumpulkan melalui observasi, wawancara, penelaahan dokumen tertulis.Untuk teknik pengujian keabsahan data melalui perpanjangan keikutsertaan, ketekunan penelitian, triangulasi, uraian rinci, auditing (praentri, penetapan dapat diaudit, kesepakatan formal, dan penentuan keabsahan).

Analisis data kualitatif merupakan usaha yang dilakukan melalui data, mengorganisasi data, mengklasifikasikan data menjadi satuan yang dapat dikelola, mensintesiskannya, mencari dan menemukan pola, menemukan apa yang diangggap penting, dan apa yang dipelajari, serta memutuskan apa yang diceritakan kepada orang lain. Untuk analisis data menggunakan analisis domain, analisis taksonomi, analisis, komponensial, dan analisis tema. Kemudian pembahasan analisis taksonomi, analisis komponensial, dan analisis tema.

\section{HASIL DAN PEMBAHASAN Analisis Domain}

Analisis domain diperoleh melalui grand tour observation dengan tujuan untuk menentukan topik penelitian. Peneliti telah melakukan grand tour observation di awal penelitian. Dari observasi di lapangan ini ditentukan topik penelitian, yaitu kepemimpinan Yesus Kristus sebagai pembawa damai. Selain itu, dari observasi di lapangan, peneliti menemukan bahwa: 1) Rentannya terjadi konflik dan kekerasan di kota Surakarta dari tahun ke tahun. 2) Kota membutuhkan kepemimpinan pembawa damai. 3) Kepemimpinan Yesus Kristus sebagai pembawa damai diharapkan dapat diteladani dan dipraktikkan oleh pemimpin Kristen untuk menciptakan perdamaian di kotamadya Surakarta, agar terwujud resolusi konflik yang membawa masyarakat Surakarta pada perdamaian, keadilan, kerukunan, toleransi, dan persaudaraan yang kuat.

\section{Analisis Taksonomi}

a. Subfokus 1: Kepemimpinan Pembawa Damai

Pemahaman tentang kepemimpinan pembawa damai ini tentu sangat penting bagi para pemimpin Kristen untuk mengetahui dan mempraktikkan dalam kehidupan bersama dengan orang-orang di sekitar yang berbeda dan majemuk dalam agama, suku, budaya dan lain sebagainya. Pemahaman tentang kepemimpinan pembawa damai sangat penting dalam pendalaman iman dan praktik hidup dalam perdamaian antara satu dengan yang lain, sehingga akan tercipta damai, sejahtera, keadilan, kerukunan, kesatuan, dan keharmonisan.

\section{b. Subfokus 2: Kepemimpinan Yesus Kristus sebagai Pembawa Damai}

Dalam mempelajarai kepemimpinan damai, Yesus Kristus adalah teladan yang tepat, karena Yesus Kristus mampu menjadi pemimpin sejati. Dia mengalami konflik dan kekerasan, namun dapat menyelesaikan dengan baik.Resolusi konflik yang dilakukan Yesuspun membawa dampak luar biasa.Karakter-karakter Yesus Kristus dapat dipraktikkan sebagai landasan dalam menciptakan perdamaian.

\section{c. Subfokus 3: Model Kepemimpinan Yesus Kristus Sebagai Pembawa Damai Bagi Resolusi Konflik di Kota Surakarta.}

Dari hasil pertanyaan subfokus tiga dapat diketahui pemahaman informan tentang pengetahuan dan praktik kepemimpinan pembawa damai dan resolusi konflik di kota Surakarta. Para pemimpin pembawa damai di kota Surakarta dapat meneladani kepemimpinan Yesus Kristus sebagai pembawa damai. 


\section{Analisis Komponensial}

\section{a. Subfokus 1: Kepemimpinan Pembawa Damai (Peacemaking Leadership)}

Kepemimpinan menyangkut banyak aspek, sehingga harus ditempati oleh orangorang yang tepat dan berintegritas, agar dapat membawa perubahan. Kepemimpinan Kristen merupakan kepemimpinan yang dilandasi atau didasari nilai dan iman Kristen, maka tidak bisa lepas dari visi-misi Allah, berpusat pada Yesus Kristus, sehingga kasih Allah sesungguhnya dapat dirasakan, menciptakan damai dalam diri manusia, dan senantiasa memuliakan Allah. Dalam kepemimpinan pembawa damai harus dapat menghadirkan tanda-tanda kehadiran Kerajaan Allah, yaitu damai sejahtera yang meliputi kerukunan, kesehatan, kehidupan yang cukup, tidak ada bencana. Karena itu, pemimpin harus memiliki prinsip, upaya, dan karakter yang kuat secara berkesinambungan.

b. Subfokus 2: Kepemimpinan Yesus Kristus sebagai Pembawa Damai

Dari hasil penelitian lapangan, informan memahami dengan baik kepemimpinan Yesus Kristus sebagai pembawa damai, baik yang berkaitan dengan gaya atau jenis kepemimpinan, konflik dan kekerasan yang dialami, pengertian resolusi konflik dan resolusi konflik yang dilakukan, pengertian karakter dan jenis-jenis karakter Yesus Kristus sebagai pembawa damai.

Yesus adalah pribadi yang anti kekerasan.Kepemimpinan nirkekerasan mengajarkan untuk mengasihi musuh, dan mendoakan orang yang menganiaya.Konflik yang dialami Yesus Kristus adalah dalam hal penerimaan dan otoritas struktural keagamaan.Konflik terjadi karena misi keagamaan berbeda dengan misi Injil Kerajaan Allah.Sedangkan kekerasan yang dialami Yesus adalah kekerasan fisik, verbal-psikhis, namun tidak mempengaruhi pribadinya.Yesus melakukan resolusi konflik dengan unik, isitimewa, dan tepat sasaran.

Jenis-jenis karakter Yesus Kristus sebagai pembawa damai bertujuan membangkitkan semangat orang agar bangkit dari keterpurukan dan memiliki semangat untuk melakukan resolusi konflik, bahkan menciptakan perdamaian, dan memperjuangkan keadilan.

c. Subfokus 3: Model Kepemimpinan Yesus Kristus Sebagai Pembawa Damai Bagi Resolusi Konflik di Kota Surakarta.

Para informan menyatakan bahwa kepemimpinan di kota Surakarta harus menghadirkan damai sejahtera di tengah masyarakat yang plural. Sehingga, kepemimpinan ini harus membawa masyarakat kota Surakarta menjadi tatanan masyarakat yang beradab, terbuka, adil, inklusif, untuk menuju pada kesejahteraan. Kepemimpinan harus merakyat dan mencapai target akhir, yaitu masyarakat damai, adil, kondusif, nyaman, dan tenteram.

Pemimpin juga harus melakukan prinsip-prinsip kepemimpinan pembawa damai. Jika prinsip-prinsip ini dilakukan, niscaya akan mempermudah terciptanya perdamaian dan keadilan. Selain itu berbagai macam upaya dalam menciptakan perdamaian harus dilakukan. Begitu juga dengan resolusi konflik dan karakter pemimpin pembawa damai, sehingga perdamaian akan tercipta, kekerasan dihentikan, konflik dikelola dengan baik, kerukunan dan keharmonisan masyarakat di kota Solo terbina dengan baik.

\section{Analisis Tema}

Pada analisis tema ini ditemukan tema umum yaitu kepemimpinan Yesus Kristus sebagai pembawa damai bagi resolusi konflik di kota Surakarta. Sedangkan tema khusus meliputi: damai kebutuhan yang hakiki, kebutuhan urgen yaitu pemimpin Kristen pembawa damai, gereja dan lembaga Kristen sebagai pusata pelayanan perdamaian, Yesus Kristus teladan pemimpin pembawa damai, konflik disertai kekerasan adalah perusak 
perdamaian, resolusi konflik sebagai cara penyelesaian konflik, dan karakter-karakter Yesus Kristus sebagai landasan perdamaian.

Berdasarkan temuan analisis data, baik temuan umum dan temuan khusus, peneliti menawarkan model kepemimpinan pembawa damai bagi resolusi konflik di kota Surakarta agar dapat digunakan sebagai acuan. Model kepemimpinan pembawa damai bagi resolusi konflik di kota Surakarta memiliki tiga komponen. Pertama, kepemimpinan pembawa damai. Dalam kepemimpinan pembawa damai ini dibagi terdiri dari prinsip-prinsip kepemimpinan pembawa damai, upaya-upaya pemimpin pembawa damai dalam menciptakan perdamaian, dan jenis-jenis karakter pemimpin pembawa damai.Kedua, resolusi konflik.Ketiga, dampak.

Model yang peneliti temukan dan tawarkan ini merupakan penggabungan antara teks dan konteks. Untuk teks atau kajian teori kepemimpinan Yesus sebagai pembawa damai. Sedangkan, konteks adalah temuan pemimpin pembawa damai di kota Surakarta (informan).

\section{Kepemimpinan Pembawa Damai}

Kepemimpinan pembawa damai (peacemaking leadership) adalah kepemimpinan yang membawa perdamaian serta memiliki isi hati, karakteristik, kekuatan mengusahakan dan membawa damai. Kepemimpinan pembawa damai memiliki karakter kuat untuk memperjuangkan kebenaran, keadilan, dan perdamaian di tengah kekacauan hidup. Dengan kata lain, kepemimpinan pembawa damai adalah kepemimpinan yang di dalamnya terdapat tindakan, spirit, pranata, dan visi menghadirkan tanda-tanda Kerajaan Allah, yaitu damai sejahtera yang berkaitan dengan kebenaran, kerukunan, keadilan, dan kesejahteraan.

\section{a. Prinsip-prinsip Kepemimpinan Pembawa Damai}

Pertama, hidup dalam kebenaran. Kedua, konsisten. Konsisten dalam hal mempraktikan kebenaran dalam kehidupan sehari-hari. Ketiga, berintegritas. Berintegritas dalam membawa dan menciptakan perdamaian dalam lingkungan. Keempat, komitmen. Komitmen untuk memperjuangkan perdamaian, keadilan, pembebasan, dan kemerdekaan.

Kelima, iman dan nilai. Keenam, kebijaksanaan. Perdamaian dunia dapat sepenuhnya dicapai hanya ketika kebijaksanaan dan upaya para pemimpin agama dunia, yang mewakili kepedulian internal dari pikiran dan hati nurani, bekerja secara kooperatif dan hormat dalam pembangunan hubungan antarumat beragama. Ketujuh, harus memiliki visi (tidak mengalir). Kedelapan, sustainable. dilakukan kegiatan yang dilakukan terusmenerus. Kesembilan, transparan, yaitu kejujuran, betul-betul bisa dipercaya dan menjadi kepercayaan. Kesepuluh, spirit berkurban. Berani berkurban dan memberi pada siapapun akan menunjukkan karakter Kristus yang benar-benar diterapkan. Kesebelas, terbuka pada kritik, yaitu bersedia dikritik atau tidak anti kritik. Keduabelas, kerjasama antar pihak. Ketigabelas, berpihak pada korban. Mendengar korban dan pemberian hak-hak kepada korban. Pemimpin harus bersedia dan memberi waktu untuk korban, serta memfasilitasi resolusi konflik, sehingga perdamaian dapat terwujud. Keempatbelas, kesetaraan. Kelimabelas, keluhuran dan kerukunan.

\section{b. Upaya-upaya Pemimpin Pembawa Damai Menciptakan Perdamaian}

Upaya-upaya pemimpin pembawa damai dalam menciptakan perdamaian adalah: Pertama, pengajaran tentang perdamaian. Urgensi teologi perdamaian adalah masalah perdamaian. Mengajarkan, membawa, dan menciptakan perdamaian berarti mencari jalan tanpa menolak tanggung jawab seseorang terhadap hak orang lain. Kedua, tindakan 
perdamaian. Setiap pemimpin perlu mengupayakan perdamaian agar tercipta keharmonisan dalam kehidupan masyarakat.

Ketiga, mengembangkan gaya hidup (life style) pembawa damai. Gaya hidup menjadi seorang pendamai, yaitu: rendah hati, mengutamakan orang lain, inisiatif mengupayakan damai, menjadi terang, tidak menyimpan kesalahan orang lain, berpikir positif, menikmati perbedaan, menjaga kebenaran dalam kasih, menyelesaikan masalah secepat mungkin, berdoa sungguh-sungguh.Keempat, membangun jejaring perdamaian. Pemimpin pembawa damai menjalin jejaring (networking) yang saling membantu untuk menciptakan proses perdamaian dan mencegah atau meminimalisasi konflik, agar tidak terjadi kekerasan. Kelima, empowering, yaitu memberi kepercayaan kepada anak-anak muda untuk meneruskan gerakan perdamaian dan keadilan. Mengkader orang untuk menjadi pemimpin perdamaian dari berbagai lapisan. Keenam, analisis SWOT dan sosial. Dengan menggunakan logika akademik seorang pemimpin harus berbekal analisis SWOT secara holistik atau menyeluruh. Ketujuh, pendampingan dan pembangunan masyarakat basis untuk perdamaian agar masyarakat tidak mudah diprovokasi. Kedelapan, transformasi laskar. Dialog dengan para laskar merupakan bagian dari transformasi. Kesembilan, riset atau kajian, yaitu skripsi, tesis, disertasi, jurnal, dan buku tentang perdamaian dan kekerasan. Kesepuluh, pendekatan kultural, yaitu pemahaman kultur Jawa yang menekankan kerukunan, harmoni, dan kearifan lokal.

c. Karakter Pemimpin Pembawa Damai

Terdapat sembilan jenis-jenis karakter pemimpin pembawa damai meliputi: kasih, pengampunan, suka damai, adil, solidaritas, rendah hati dan menghargai lemah lembut dan tegas, terbuka dan bersahabat, berani dan bertanggung jawab. Berikut penjelasan lengkapnya:

\section{Resolusi Konflik}

Resolusi konflik memiliki beberapa makna. Pertama, resolusi konflik suatu tindakan mengurai permasalahan, pemecahan atau penghapusan permasalahan membutuhkan keterampilan dan penilaian untuk bernegosiasi, kompromi, serta mengembangkan rasa keadilan. Kedua, resolusi konflik adalah komitmen, perjanjian, kesepakatan, kesepahaman untuk menyelesaikan konflik, berpihak pada kebenaran.

Resolusi konflik yang dilakukan meliputi: Pertama, komunikasi (mendengar). Kedua, pengendalian diri. Keempat, pengembangan sikap pengampunan, adil, dan sabar. Kelima, menarik diri. Keenam, berani menghadapi. Ketujuh, dialog dan kerjasama. Kedelapan, healing pada laskar. Kesembilan, team teaching. Kesepuluh, pengembangan ekonomi.

\section{Dampak}

Dampak dari kepemimpinan pembawa damai adalah: Pertama, terciptanya perdamaian antara Allah dan manusia.Kedua, penghentian kekerasan.Ketiga, regenerasi dan suksesi pemimpin pembawa damai. Keempat, terbina kerukunan antar agama dan golongan. Kelima, munculnya periset dan pengkaji perdamaian.Keenam, sinergitas antara pemerintah kota, tokoh agama, dan masyarakat.

\section{SIMPULAN}

Kesimpulan penelitian ini adalah sebagai berikut: Pertama, kota Surakarta merupakan kota yang rentan dengan konflik maupun kekerasan, sehingga membutuhkan kepemimpinan pembawa damai yang dapat membawa masyarakat kepada situasi damai, sejahtera, rukun, harmoni, adil, dan saling menghargai. Kedua, kepemimpinan Yesus 
Kristus sebagai pembawa damai menjadi teladan bagi pemimpin pembawa damai (khususnya pemimpin Kristen) dalam melakukan resolusi konflik demi terciptanya perdamaian dan keadilan, terhentinya kekerasan, dan kehidupan yang saling mengasihi, menghargai, serta menghormari antar agama, golongan, dan masyarakat umum. Ketiga, pemimpin pembawa damai di Kota Surakarta telah melaksanakan fungsi sebagai pembawa damai dan melakukan resolusi konflik.Akan tetapi, dalam pelaksanaannya masih perlu ditingkatkan.Untuk meningkatkan efektivitas dan kualitas kepemimpian pembawa damai, maka perlu dikaji dan dilengkapi agar berdampak secara tepat dan cepat, demi terciptanya masyarakat yang hidup dalam kedamaian, keadilan, dan kesejahteraan.

Keempat, penelitian ini bertujuan untuk menemukan suatu model kepemimpinan pembawa damai bagi resolusi konflik di kota Surakarta yang alkitabiah, relevan, dan kontekstual. Melalui penelitian ini, maka ditemukan sejumlah masalah dominan yang terjadi yaitu: minimnya pemimpin Kristen yang bersedia terjun dalam pelayanan perdamaian di kota Surakarta, masih kurangnya peran pemimpin gereja dan lembaga Kristen sebagai penggerak pelayanan perdamaian, masih terjadi konflik yang disertai dengan kekerasan di kota Surakarta. Karena itu, untuk menghadapi permasalahan ini, peneliti menemukan Model Kepemimpinan Pembawa Damai Bagi Resolusi Konflik di Kota Surakarta yang memiliki tiga komponen, yaitu kepemimpinan pembawa damai, resolusi konflik, dan dampak. (1) Kepemimpinan pembawa damai. Kepemimpinan damai adalah kepemimpinan yang di dalamnya terdapat tindakan, spirit, pranata, dan visi menghadirkan tanda-tanda Kerajaan Allah, yaitu damai sejahtera yang berkaitan dengan kebenaran, kerukunan, keadilan, dan kesejahteraan. Dalam kepemimpinan pembawa damai ini terdiri dari: (a) prinsip-prinsip kepemimpinan pembawa damai yaitu: hidup dalam kebenaran, konsisten, berintegritas, berjuang bagi keadilan, iman dan nilai-nilai, kebijaksanaan, visi, sustainable, transparan, spirit berkurban, terbuka pada kritik, kerjasama, berpihak pada korban, kesetaraan, keluhuran dan kerukunan. (b) upay-upaya pemimpin pembawa damai dalam menciptakan perdamaian, yaitu: mengajarkan perdamaian, tindakan perdamaian (menciptakan, menjaga, dan menggalang), gaya hidup perdamaian, jejaring, empowering, analisis SWOT dan sosial, pendampingan masyarakat basis perdamaian, transformasi para laskar, riset dan kajian, pendekatan kultural. (c) jenisjenis karakter pemimpin pembawa damai, yaitu: kasih (belas kasihan), pengampunan (mengampuni), adil, suka damai, solidaritas, rendah hati dan menghargai, lemah lembut dan tegas, terbuka dan bersahabat, berani dan bertanggung jawab. (2) Resolusi konflik. Definisi resolusi konflik adalah tindakan mengurai permasalahan, pemecahan permasalahan yang membutuhkan keterampilan dan penilaian yang adil. Resolusi juga berarti komitmen, kesepahaman untuk menyelesaikan konflik, berpihak pada kebenaran, penghentian kekerasan, penciptaan perdamaian. Resolusi konflik yang dilakukan meliputi: komunikasi (mendengar), pengendalian diri, menyambut konflik, pengembangan sikap (mengampuni, adil, sabar), menarik diri, berani menghadapi, dialog, healing, team teaching, dan pengembangan ekonomi. (3) Dampak. Dampak yang muncul adalah: terciptanya perdamaian, penghentian kekerasan, regenerasi dan suksesi pemimpin pembawa damai, terbina kerukunan (agama dan golongan), munculnya periset, pengkaji perdamaian, sinergitas (pemerintah kota, tokoh agama, dan masyarakat).

Beberapa rekomendasi bagi pemimpin gereja dan lembaga Kristen (media Kristen, institusi teologi, dan lain-lain), jemaat atau tubuh Kristus, bagi para peneliti perdamaian, dan pembaca. Pertama, bagi pemimpin pembawa damai (khususnya pemimpin gereja dan lembaga Kristen) di kota Surakarta dapat menerapkan Model Kepemimpinan Pembawa Damai Bagi Resolusi Konflik di Kota Surakarta yang peneliti jelaskan melalui penelitian disertasi ini. Model ini dapat dijadikan acuan dalam menciptakan perdamaian dan melakukan resolusi konflik, karena model ini meneladani Yesus Kristus sebagai teladan 
pemimpin pembawa damai, baik yang berkaitan dengan prinsip-prinsip kepemimpinan pembawa damai, upaya-upaya pemimpin pembawa damai dalam menciptakan perdamaian, karakter-karakter pembawa damai, resolusi konflik, maupun dampak yang dihasilkan. Sehingga, kondisi di kota Surakarta akan damai, adil, rukun, harmoni, saling mengasihi, dan menghargai di antara agama, golongan, pemerintah, dan masyarakat umum.Kedua, berkaitan dengan sejumlah permasalahan dominan yang terjadi, yaitu: minimnya pemimpin Kristen yang bersedia terjun dalam pelayanan perdamaian di kota Surakarta, masih kurangnya peran pemimpin gereja dan lembaga Kristen sebagai pusat pelayanan perdamaian, serta masih terjadi konflik yang disertai dengan kekerasan di kota Surakarta, maka pemimpin gereja dan lembaga Kristen harus mengajarkan perdamaian dengan memprogramkan dan menganggarkan dana untuk perdamaian dalam Informasi Rencana Program (IRP) dan Rencana Anggaran Belanja (RAB). Hal ini dapat dilakukan dengan kegiatan pengajaran perdamaian melalui khotbah, pendalaman Alkitab (PA) ataupun pemuridan, katekisasi, program siaran perdamaian, dialog antar agama dan golongan, kaderisasi pemimpin pembawa damai, pelatihan perdamaian, dan lain sebagainya. Ketiga, pemimpin gereja dan lembaga Kristen perlu membuat modul atau kurikulum perdamaian yang dapat diajarkan dan dipraktikkan dalam penciptaan perdamaian, promosi, kaderisasi, dan suksesi kepemimpinan pembawa damai. Contoh modul atau kurikulum perdamaian yang terdiri dari tema, sasaran, dan pertemuan dapat dilihat di lampiran disertasi ini. Keempat, pemimpin gereja dan lembaga Kristen perlu meningkatkan kerjasama dan hubungan yang sinergi dengan pemerintah kota, tokoh agama, tokoh masyarakat, tokoh partai politik, akademisi, kaum profesi, dan masyarakat untuk bersama-sama mendukung program perdamaian, sehingga konflik dapat ditangani dengan baik, kekerasan dihentikan, aksi perdamaian ditingkatkan. Adapun kerjasamanya dilakukan dalam bentuk: dialog, seminar kebangsaan dan perdamaian, pemberdayaan dan pendampingan komunitas basis perdamaian di tingkat RT dan RW. Kelima, berkaitan dengan pengembangan ilmu pengetahuan, maka institusi teologi (Sekolah Tinggi Teologi, Institut Teologi) dapat menggunakan penelitian ini menjadi salah satu acuan dalam mengembangkan teori kepemimpinan, khususnya model kepemimpinan pembawa damai, karena penelitian ini menyediakan prinsip-prinsip teologis dan teori-teori modern tentang model kepemimpinan yang alkitabiah dan kontekstual yang dapat dijadikan sebagai mata kuliah dalam kurikulum akademik. Bahkan, dapat dilakukan riset dan kajian tentang perdamaian dalam bentuk jurnal, skripsi, tesis, maupun disertasi. Keenam, bagi para peneliti dan pembaca yang tertarik dan ingin mendalami perdamaian untuk dapat dipraktikkan di konteksnya masingmasing dengan melakukan riset dan kajian seputar perdamaian (misalnya, jurnal perdamaian).

\section{DAFTAR PUSTAKA}

Aquinas, Thomas, Summa Theologiae, II-II, q.30.a.4.

Aritonang, Jan Sihar \& Gomar Gultom, Tuhan itu Baik Kepada Semua Orang, (Jakarta: PGI, 2009).

Betz, Hans Dieter, The Sermon on the Mount: A Commentary on the Sermon on the Mount Including the Sermon on the Plain, (Minneapolis: Fortress, 1995).

Chandra, Robby I., Transformasi, (Bekasi: Bina Warga, 2000).

Chen, Febe, Competence for Success: Karakter \& Motivasi, (Jakarta: Gramedia Pustaka Utama, 2011).

Desjardins, Michael, Peace, Violence and the New Testament, (Sheffield: Sheffield

Academic Press, 1997).

Enright, Robert D., Forgiveness is a Choice, (Washington: APA, 2001).

Gruchy, John W., Agama Kristen dan Demokrasi, (Jakarta: BPK Gunung Mulia, 2003). 
Hayford, Jack W., Leaders On Leadership, Pandangan Para Pemimpin Tentang Kepemimpinan, (Malang: Penerbit Gandum Mas, 2002).

Kurniawati, Maryam, Pendidikan Kristiani Multikultural, (Tangerang: Bamboo Bridge, 2014).

Lawson, Michael, Conflict, (Yogyakarta: ANDI, 2009).

Lederach, John Paul, Transformasi Konflik, (Yogyakarta: Duta Wacana University Press, 2005).

Leland, Robert E., Memancarkan Citra-Nya, (Yogyakarta: ANDI, 2004).

Lincoln, Erick, Irfan AmaLee, Nggak Gengsi Ngaku Salah: Tentang Mengaku Kesalahan (Bandung: Pelangi Mizan, 2007).

Little, David, Peacemakers in Action: Profiles of Religion in Conflict Resolution, (New York: Cambridge University Press, 2007).

Luskin, Fred, Forgive for Love: The Missing Ingredient for a Healthy and Lasting Relationship, (Harper Collin, 2007).

Moon, Sun Myung, Happy Unification Church Members, (New York, New York: HSAUWC Publication, 1977).

Moon, Sun Myung, "Renewing the United Nations and Building a Culture of Peace," A Report from Assembly 2000, (New York: Interreligious and International Federation for World Peace, 2000).

Ndoen, Bram Soei, 7+1 SOS Sector Organism of Success, (Jakarta: Gramedia pustaka Utama, 2012).

Nurcholis, Ahmad, Alamsyah M. Dja'far, Agama Cinta, (Jakarta: Elex Media Komputindo, 2015).

Palmer, Donald, Managing Conflict Creatively, (England: William Carey Library, 1990).

Poerwadarminta, W.J.S., Kamus Umum Bahasa Indonesia, (Jakarta: Balai Pustaka, 2006).

Setiawan, Budi, Paradigma Yesus, (Malang: Gandum Mas, 2009).

State of the World Forum, People Building Peace, 35 Inspiring Stories from Around the World, (International Books, 1999).

Sudarmanto, G. Teologi Multikultural, (Batu: Departemen Multimedia YPPII Batu, 2014).

Sudarmanto, YB, Agama dan Politik Anti Kekerasan, (Yogyakarta: Kanisius, 1989.

Sukri, Lina, Living With Purpose, (Jakarta: Gramedia Pustaka Utama, 2013).

Swartley, Williard M., The Love of Enemy and Nonretaliation in the New Testament, (Louisville, Ky: Westminter John Knox Press, 1992).

Tadjoeddin, Mohammad Zulfan, Anatomy of Social Violence in the Context of Transition: The Case if Indonesia 1990-1991, (UNSFIR Working Papers, 2002).

Tomatala, Yakob, Pemimpin yang Handal, (Jakarta: YT Leadership Goundation, 2001).

Wallensteen, Peter, Understanding Conflic \& Resolution, (USA: Sage Publication Ltd., 2007).

Yahya, Kresnayana, Tantangan Pendidikan Abad 21, (Surabaya: Enciety, 2017).

Yewangoe, Andreas A., Tidak Ada Negara Agama, (Jakarta: BPK Gunung Mulia, 2009).

Yoder, John, The Priestly Kingdom: Social Ethics as Gospel, (University of Notredame Press, 1984).

Zoschak, Greg, Membangun Karakter Anda, (Jakarta: Immanuel, 2003). 